\title{
Protective effect of cinnamon against cadmium-induced hepatorenal oxidative damage in rats
}

\author{
Ahmed Ghonim 1, 2, Ahmed Abdeen ${ }^{1}$, Ragab El-Shawarby ${ }^{1}$, Nabila Abdel-Aleem ${ }^{1}$, \\ Elham El-Shewy ${ }^{1}$, Mohamed Abdo ${ }^{3}$, Ehab Abdelhiee ${ }^{1}$ \\ ${ }^{1}$ Department of Forensic Medicine and Toxicology, Faculty of Veterinary Medicine, Benha University, Toukh 13736, Egypt \\ ${ }^{2}$ Teaching hospital, Faculty of Veterinary Medicine, Menufyia University, Shebin Elkoum 32514, Egypt \\ ${ }^{3}$ Department of Anatomy and Embryology, Faculty of Veterinary Medicine, University of Sadat City, Menufyia 22857, Egypt \\ *Corresponding author E-mail: ahmed.abdeen@fvtm.bu.edu.eg
}

\begin{abstract}
Background: Cadmium (Cd) is a well-known hazardous environmental contaminant. It exerts its toxicity through induction of lipid peroxidation and reduction of cellular antioxidant. Therefore, in this study, we investigated whether cinnamon could protect against Cd toxicity in liver and kidney.

Materials and methods: Forty male Wister rats (130-135 gm) were divided randomly into 4 groups/ 10 rats each. Control, cinnamon, cadmium, and Cinn $+\mathrm{Cd}$ groups received distilled water, cinnamon extract $(200 \mathrm{mg} / \mathrm{kg} \mathrm{b}$.wt. orally), cadmium chloride (5 mg/kg b.wt. orally), and Cd plus cinnamon, respectively. Blood, liver, and kidney samples were collected after 8 weeks of treatment. Erythrogram, leukogram, liver and kidney functions, and oxidative status (MDA, CAT, and TAC) were determined.

Results and discussion: Cd-treated animals showed significant increases in serum ALT, AST, creatinine, and urea indicating hepatic and renal damage. Cd-induced oxidative stress was observed by marked decease TAC accompanied by increase in MDA which contributed in liver and kidney dysfunction. Co-treatment of $\mathrm{Cd}$ with cinnamon has improved the oxidation profile by increasing the TAC and decreasing the lipid peroxidation. Cinnamon ameliorated the toxic effect of $\mathrm{Cd}$, which observed by improvement of liver and kidney functions.
\end{abstract}

Conclusion: High antioxidants content of cinnamon could protect the liver and kidney from Cd toxicity.

Keywords: antioxidants, cadmium, cinnamon, reactive oxygen species.

\section{Introduction}

Cadmium (Cd), is considered one of the most hazardous metal among other heavy metals. Cd is a serious environmental and occupational contaminant that causes very toxic effect to humans and animals even in small amounts (Singh et al. 2013). Previous studies have reported that $\mathrm{Cd}$ produced long-term negative impact on health by producing a wide range of biochemical and physiological dysfunctions in humans and laboratory animals including hepatic, renal, and testicular damage (Nigam et al. 1999, Yiin et al. 1999, Santos et al. 2004, Newairy et al. 2007, Singh et al. 2007). Cd has a great affinity to various biological components such as sulfhydryl containing proteins, macromolecules, and metallothionein (Klassen et al. 1999). Cd-metallothionein complex is generated in the liver and then distributed to other tissues mainly kidney causing tubular damage (Liu et al. 1996, Tremellen 2008, Turner \& Lysiak 2008).

The mechanisms underlying Cd toxicity is regarding mainly to its oxidative damage. It has been reported that $\mathrm{Cd}$ induces production of reactive oxygen species (ROS) including superoxide anion, hydrogen peroxide, and hydroxyl radical (Toppo et al. 2015). These ROS react with several cellular molecules causing lipid peroxidation, protein oxidation, DNA damage, and ultimately induce apoptosis (Stohs et al. 2000). Moreover, Cd inhibits the endogenous antioxidants such glutathione peroxidase, reduced glutathione, catalase, and superoxide dismutase leading to accu- mulation of free radicals inside the cell resulting in cell damage (Amara et al. 2011). Based on the previously mentioned, conducting research aimed for counteracting the $\mathrm{Cd}$-induced oxidative damage would be of great importance.

On the other hand, one of the most widely used medicinal plants is cinnamon (Cinnamomum cassia) that contains high concentrations of antioxidants (Su et al. 2007, Eidi et al. 2012). Cinnamon therefore has a role in hepatoprotective and nephroprotective effect as well as in cancer remedy (Nishida et al. 2003, Moselhy \& Ali 2009, Sakr \& Albarakai 2014, Elkomy et al. 2016).

Therefore, in the current study, we investigated whether cinnamon could protect against $\mathrm{Cd}$-induced hepatic and renal oxidative damage in rats. The results revealed that cinnamon could decrease the hepatic and renal damage exerted by $\mathrm{Cd}$ insult.

\section{Materials and methods}

\subsection{Medicinal plant}

Cinnamon barks were purchased from retail market, Cairo, Egypt. The plant was identified by Department of Botany, Faculty of Science, Benha University, Egypt. The dried cinnamon was grinded into a fine powder. The dried powder was then soaked in distilled water (10 gm powder/ $100 \mathrm{ml}$ distilled water) for $2 \mathrm{~h}$ at $90^{\circ} \mathrm{C}$. The soaking solution was filtered and the filtrate was then 
dehydrated in hot air oven at $80{ }^{\circ} \mathrm{C}$ overnight. The resulted dark reddish brown dry extract was weighed (Morgan et al. 2014).

\subsection{Animals}

Forty male Wistar rats (130-135 gm) were purchased from the Animal House, Faculty of Veterinary Medicine, Benha University, Egypt. They were fed on a standard pellet diet and tap water was provided ad libitum. All rats were acclimatized to the environment for 2 weeks prior to experiment. This study was approved by the Ethics Committee of animals.

After acclimatization, all rats were divided randomly into 4 groups/10 rats each. Control group; received distilled water, cinnamon group; received cinnamon extract ( $200 \mathrm{mg} / \mathrm{kg}$ b.wt. orally), cadmium group; received cadmium chloride $(5 \mathrm{mg} / \mathrm{kg} \mathrm{b}$. wt. orally), and Cinn+Cd group; received cadmium chloride $(5 \mathrm{mg} / \mathrm{kg} \mathrm{b}$ wt. orally) and cinnamon extract ( $200 \mathrm{mg} / \mathrm{kg} \mathrm{b.wt.} \mathrm{orally).} \mathrm{After} 8$ weeks, all animals were killed under anesthesia and samples were collected.

\subsection{Analyses of blood parameters}

Blood samples were collected from retro orbital plexus after 8 weeks of experiment and taken on anticoagulant, $10 \%$ disodium EDTA $(20 \mu \mathrm{l} / \mathrm{ml}$ blood) was used for hematological studies. Other blood samples were taken without anticoagulant for serum biochemical studies.

\subsubsection{Hematological studies}

The hematological studies included erythrogram and leukogram and differential leucocytic counts were evaluated at the end of the experiment (after 8 weeks) directly by using automatic cell counter (H.A-Vet Clindiage, Belgium) which depends on both electrical and optical techniques according to Knapp et al. 1996.

The erythrogram includes hemoglobin concentration $(\mathrm{Hb})$, total erythrocyte cell count (RBCs), and haematocrite (HCT). While, the leukogram includes several parameters such as total leukocytic count (WBCs), lymphocyte, monocyte, and granulocyte count.

\subsubsection{Serum biochemical studies}

Serum alanine aminotransferase (ALT), aspartate aminotransferase (AST), urea, creatinine, total protein, and albumin were measured using diagnostic kits (Centronic $\mathrm{GmbH}$, Wartenberg, Germany). ALT and AST were estimated according to Z. Klin 1972. Urea and creatinine were determined according to Eisenwiener 1976, Allen 1982 respectively. While, total protein and albumin were evaluated according to Gornall 1949, Doumas et al 1971 respectively. Alkaline phosphatase (ALP) was determined by using special diagnostic kit (Stan Bio laboratory, Texas, USA) according to Demetrious et al. 1974. All parameters were measured colorimetry using a spectrophotometer (JASCO 7800, uv/vis, Japan).

\subsection{Evaluation of oxidative status}

The levels of catalase (CAT), malondialdehyde (MDA), and total antioxidant capacity (TAC) were determined by using special diagnostic kits (Bio diagnostic company, Egypt) according to Aebi 1984, Satoh 1978, Koracevic et al. 2001 respectively.

Preparation of liver and kidney homogenates: tissue sample was washed with PBS ( $\mathrm{pH} 7.4$ ) containing $0.16 \mathrm{mg} / \mathrm{ml}$ heparin to remove any red blood cells and clots. One gram of each tissue was homogenized in 5-10 $\mathrm{ml}$ cold buffer (i.e. $50 \mathrm{mmol}$ potassium phosphate, $\mathrm{pH} 7.5 .1 \mathrm{mmol}$ EDTA) per gram tissue, using sonicator homogenizer. Aliquots of tissue homogenates were centrifuged using cool centrifuge $4000 \mathrm{rpm}$ for $20 \mathrm{~min}$ then stored at $-20^{\circ} \mathrm{C}$ till analysis.

\subsection{Histopathological studies}

Liver and kidney samples were collected in $10 \%$ formalin. Samples were washed under tap water then serial dilutions of alcohol (methyl, ethyl, and absolute ethyl) were used for dehydration. Specimens were cleared in xylene and embedded in paraffin at $56{ }^{\circ} \mathrm{C}$ in hot air oven for $24 \mathrm{~h}$. Paraffin bees wax tissue blocks were prepared for sectioning at $4 \mu \mathrm{m}$. Next, tissue sections were deparffinized and stained by hematoxylin and eosin stains (Banchroft, et al. 1996) for further histopathological examination.

\subsection{Statistical analysis}

Statistical analysis was performed using the statistical software package SPSS for Windows (Version 20.0; SPSS Inc., Chicago, IL, USA). The significance of differences between groups was evaluated by one-way ANOVA using Duncan test as a post hoc. Results are expressed as mean \pm standard error (SE). $\mathrm{P}$ value $<0.05$ was considered significant.

\section{Results}

\subsection{Effect of cinnamon and/or cadmium on hematology}

As shown in Table (1), rats administrated Cd showed significant decreases in RBCs count, Hb concentration, and HCT comparing to the control group indicating a normocytic normochromic anemia induced by $\mathrm{Cd}$ insult. While, in animals co-administrated $\mathrm{Cd}$ and cinnamon showed recovery in the same parameters but still not significant in comparison to control group. Moreover, there was a significant increase in the total WBCs count, lymphocytes, and granulocytes with no changes in monocytes in Cd treated animals when compared to control animals. These data suggesting that $\mathrm{Cd}$ has exerted degenerative changes in the different body tissues. There also were no significant changes in hematogical picture between cinnamon and control group.

Table 1: Effect of cinnamon and / or cadmium on hematological parameters $(n=10)$

\begin{tabular}{lllll}
\hline Parameters & Control & Cinnamon & Cadmium & Cinn+Cd \\
\hline $\begin{array}{l}\mathrm{RBC}_{\mathrm{S}} \\
\left(10^{12} / \mathrm{L}\right)\end{array}$ & $8.11 \pm 0.14^{\mathrm{b}}$ & $7.82 \pm 0.33^{\mathrm{b}}$ & $6.41 \pm 0.38^{\mathrm{a}}$ & $7.10 \pm 0.28^{\mathrm{ab}}$ \\
$\mathrm{Hb}(\mathrm{g} / \mathrm{dl})$ & $12.67 \pm 0.33^{\mathrm{b}}$ & $11.37 \pm 0.94^{\mathrm{ab}}$ & $9.73 \pm 0.81^{\mathrm{a}}$ & $12.03 \pm 0.13^{\mathrm{ab}}$ \\
$\mathrm{HCT}(\%)$ & $48.14 \pm 1.56^{\mathrm{b}}$ & $47.21 \pm 2.02^{\mathrm{ab}}$ & $40.99 \pm 2.23^{\mathrm{a}}$ & $46.01 \pm 0.65^{\mathrm{ab}}$ \\
$\begin{array}{l}\mathrm{WBC}_{\mathrm{S}} \\
\left(10^{9} / \mathrm{L}\right)\end{array}$ & $9.57 \pm 0.45^{\mathrm{a}}$ & $10.80 \pm 0.52^{\mathrm{a}}$ & $17.73 \pm 0.82^{\mathrm{b}}$ & $11.27 \pm 0.54^{\mathrm{a}}$ \\
$\begin{array}{l}\text { Lympho- } \\
\text { cyte }\left(10^{9} / \mathrm{L}\right)\end{array}$ & $1.95 \pm 0.59^{\mathrm{a}}$ & $1.06 \pm 0.54^{\mathrm{a}}$ & $5.47 \pm 0.55^{\mathrm{b}}$ & $1.43 \pm 0.37^{\mathrm{a}}$ \\
$\begin{array}{l}\text { Monocytes } \\
\left(10^{9} / \mathrm{L}\right)\end{array}$ & $1.92 \pm 0.20^{\mathrm{a}}$ & $2.58 \pm 0.44^{\mathrm{a}}$ & $2.33 \pm 0.12^{\mathrm{a}}$ & $2.53 \pm 0.17^{\mathrm{a}}$ \\
$\begin{array}{l}\text { Granulocyte } \\
\left(10^{9} / \mathrm{L}\right)\end{array}$ & $5.72 \pm 0.24^{\mathrm{a}}$ & $7.16 \pm 0.22^{\mathrm{b}}$ & $9.94 \pm 0.22^{\mathrm{c}}$ & $7.31 \pm 0.74^{\mathrm{b}}$ \\
\hline
\end{tabular}

Data expressed as mean $\pm \mathrm{SE}$

Means within the same raw with different letters are statistically significant $(\mathrm{P}<0.05)$

\subsection{Effect of cinnamon and/or cadmium on biochemical parameters of liver and kidney}

In Table (2), Cd group showed dramatic increases in the liver function parameters (ALT, AST, and ALP) compared to the control group. These data confirm the toxic effect of $\mathrm{Cd}$ on liver. Moreover, there were drastic increases in the kidney functions including serum creatinine and urea in animals received $\mathrm{Cd}$ when compared to the control animals (Table 2). In addition, the significant decreases in the total serum protein and albumin in the $\mathrm{Cd}$ group in comparison to control group (Table 2) indicating loss of protein in the urine, which may be contributed to impaired glomerular filtration. These data suggest that $\mathrm{Cd}$ caused damage in the renal tubules. 
Interestingly, the rats co-administrated $\mathrm{Cd}$ and cinnamon showed significant improvements in the liver and kidney functions when compared to the control and Cd groups (Table 2). On the other hand, there were no significant changes in the liver and kidney function parameters in the cinnamon group in comparison to the control group.

Table 2: Effect of cinnamon and / or cadmium on biochemical parameters $(n=10)$

\begin{tabular}{|c|c|c|c|c|}
\hline Parameters & Control & Cinnamon & Cadmium & Cinn+Cd \\
\hline ALT (U/l) & $13.64 \pm 1.27^{\mathrm{a}}$ & $12.58 \pm 0.91^{\mathrm{a}}$ & $44.52 \pm 2.15^{\mathrm{c}}$ & $31.06 \pm 0.85^{\mathrm{b}}$ \\
\hline AST (U/l) & $63.21 \pm 4.73^{\mathrm{a}}$ & $69.44 \pm 3.60^{\mathrm{a}}$ & $121.90 \pm 3.63^{c}$ & $92.70 \pm 5.20^{\mathrm{b}}$ \\
\hline $\operatorname{ALP}(\mathrm{U} / \mathrm{l})$ & $149.63 \pm 31.44^{\mathrm{a}}$ & $179.20 \pm 21.39^{\mathrm{ab}}$ & $326.97 \pm 19.86^{\mathrm{c}}$ & $229.30 \pm 4.48^{\mathrm{b}}$ \\
\hline $\begin{array}{l}\text { Urea } \\
(\mathrm{mg} / \mathrm{dl})\end{array}$ & $122.88 \pm 2.30^{\mathrm{a}}$ & $127.67 \pm 2.02^{\mathrm{ab}}$ & $150.10 \pm 5.27^{\mathrm{c}}$ & $136.37 \pm 4.41^{\mathrm{b}}$ \\
\hline $\begin{array}{l}\text { Creatinine } \\
(\mathrm{mg} / \mathrm{dl})\end{array}$ & $0.58 \pm 0.04^{\mathrm{a}}$ & $0.62 \pm 0.04^{\mathrm{a}}$ & $1.05 \pm 0.04^{\mathrm{c}}$ & $0.76 \pm 0.05^{\mathrm{b}}$ \\
\hline $\begin{array}{l}\text { Protein } \\
\text { (gm/dl) }\end{array}$ & $6.07 \pm 0.29^{c}$ & $5.53 \pm 0.08^{b}$ & $4.41 \pm 0.08^{\mathrm{a}}$ & $5.36 \pm 0.16^{\mathrm{b}}$ \\
\hline $\begin{array}{l}\text { Albumin } \\
\text { (gm/dl) }\end{array}$ & $3.65 \pm 0.21^{\mathrm{b}}$ & $3.11 \pm 0.30^{\mathrm{ab}}$ & $2.70 \pm 0.16^{\mathrm{a}}$ & $3.11 \pm 0.37^{\mathrm{ab}}$ \\
\hline
\end{tabular}

Data expressed as mean $\pm \mathrm{SE}$

Means within the same raw with different letters are statistically significant $(\mathrm{P}<0.05)$

\subsection{Effect of cinnamon and/or cadmium on oxidative status in the liver and kidney tissues}

Data in Table (3) revealed that $\mathrm{Cd}$ insult could dramatically decrease the level of CAT along with increase in the MDA in liver and kidney in comparison with the control. Cd insult significantly decreased the TAC in kidney but not in liver.

Expectedly, rats received cinnamon and $\mathrm{Cd}$ showed improvements in the levels of CAT, MDA, and TAC in liver and kidney compared to control rats. Because of the cinnamon group did not show any significant changes when compared to the control group, it is suggested cinnamon has a role in counteracting the oxidative damage induced by $\mathrm{Cd}$.

Table 3: Effect of cinnamon and / or cadmium on oxidative cascade $(n=10)$

\begin{tabular}{lllll}
\hline Parameters & Control & Cinnamon & Cadmium & Cinn+Cd \\
\hline $\begin{array}{l}\text { CAT liver } \\
\text { (U/gm) }\end{array}$ & $182.71 \pm 11.72^{\mathrm{b}}$ & $170.02 \pm 9.45^{\mathrm{b}}$ & $130.85 \pm 12.78^{\mathrm{a}}$ & $158.07 \pm 4.16^{\mathrm{ab}}$ \\
$\begin{array}{l}\text { CAT kid- } \\
\text { ney (U/gm) }\end{array}$ & $309.77 \pm 34.94^{\mathrm{b}}$ & $297.91 \pm 66.44^{\mathrm{ab}}$ & $152.55 \pm 15.10^{\mathrm{a}}$ & $200.29 \pm 17.53^{\mathrm{ab}}$ \\
$\begin{array}{l}\text { MDA } \\
\text { liver } \\
(\mathrm{nmol} / \mathrm{gm})\end{array}$ & $654.05 \pm 26.84^{\mathrm{ab}}$ & $545.38 \pm 64.14^{\mathrm{a}}$ & $742.70 \pm 72.13^{\mathrm{b}}$ & $310.45 \pm 6.49^{\mathrm{ab}}$ \\
$\begin{array}{l}\text { MDA } \\
\text { kidney } \\
(\mathrm{nmol} / \mathrm{gm})\end{array}$ & $247.67 \pm 14.84^{\mathrm{a}}$ & $238.85 \pm 19.04^{\mathrm{a}}$ & $366.27 \pm 30.21^{\mathrm{b}}$ & $310.45 \pm 6.49^{\mathrm{b}}$ \\
$\begin{array}{l}\text { TAC liver } \\
(\mathrm{mmol} / \mathrm{l})\end{array}$ & $1.37 \pm 0.12^{\mathrm{ab}}$ & $1.58 \pm 0.29^{\mathrm{b}}$ & $0.98 \pm 0.04^{\mathrm{a}}$ & $1.24 \pm 0.14^{\mathrm{ab}}$ \\
$\begin{array}{l}\text { TAC kid- } \\
\text { ney } \\
(\mathrm{mmol} / \mathrm{l})\end{array}$ & $1.77 \pm 0.03^{\mathrm{c}}$ & $1.75 \pm 0.02^{\mathrm{c}}$ & $1.34 \pm 0.06^{\mathrm{a}}$ & $1.57 \pm 0.05^{\mathrm{b}}$ \\
\hline
\end{tabular}

Data expressed as mean $\pm \mathrm{SE}$

Means within the same raw with different letters are statistically significant $(\mathrm{P}<0.05)$

\subsection{Effect of cinnamon and/or cadmium on histopatho- logical findings in liver and kidney tissues}

Next, to confirm the previous data, we examined the histopathology of liver and kidney. As shown in Fig. 1C, rats administrated Cd showed extensive destruction in the architecture of liver and kidney. There were fatty changes detected in diffuse manner all over the hepatocytes associated with dilatation and congestion in both central and portal veins as well as edema in the portal area and dilatation in the bile. While, in kidney, there was focal in- flammatory cells infiltration in between the degenerated tubules at the cortex (Fig. 2C). These histopathological findings confirmed the hepatorenal-toxic effect of $\mathrm{Cd}$.

In contrast, rats received cinnamon and $\mathrm{Cd}$ showed improvement in the histology of liver and kidney in comparison to control group (Fig. 1D and 2D, respectively).

\section{Discussion}

$\mathrm{Cd}$ is one of the most toxic pollutants among other environmental pollutants. Cd is known to induce oxidative damage by enhancing production of ROS inside the cell. Liver and kidney are the main target organs for Cd (Nigam et al. 1999, Newairy et al. 2007, Tremellen 2008, Turner \& Lysiak 2008, Abernethy et al. 2010). Moreover, there are many appreciated studies have demonstrated the potential use of cinnamon, an enriched source of antioxidants, as ROS scavenger (Su et al. 2007, Moselhy \& Ali 2009, Sakr \& Albarakai 2014). Therefore, this study aimed to investigate the antioxidant power of cinnamon against $\mathrm{Cd}$-induced oxidative damage in liver and kidney.

$\mathrm{Cd}$ has a great affinity for $\mathrm{SH}$-containing molecules inside the cell such as glutathione (GSH) and metllothionein (MT). MT is a cysteine-SH rich protein which is important in detoxification of $\mathrm{Cd}$ through formation of Cd-MT complex. Because liver and kidney are rich in MT, they are known to be the major target organs for Cd accumulation (Bagchi et al. 1996, Rikans \& Yamano 2000, Hollis et al. 2001, Massanyi et al. 2003). Hence, SH group is involved in the function of many enzymes, the $\mathrm{Cd}-\mathrm{SH}$ complex possibly disturb many functions of cell mainly mitochondrial dysfunction. Interacting of $\mathrm{Cd}$ with the redox system in the mitochondria enhances over production of ROS and their release into the cytoplasm inducing apoptotic cascade (Radosavljevici et al. 2012). In the current study, firstly, the hepatotoxic effect of $\mathrm{Cd}$ was demonstrated by elevated ALT, AST, and ALP levels. The increased ALT, AST, and ALP levels may be attributed to the hepatocellular degeneration as a result of $\mathrm{Cd}$-induced oxidative damage in the liver which observed by depletion of hepatic CAT and TAC, as seen in Table (3). It is also possibly attributed to Cd-induced lipid peroxidation which observed by marked increase the MDA level (Table 3), supporting the data reported in the previous studies (Kara et al. 2005, Lakshmi et al. 2012, Tribowo et al. 2014). MDA is the major aldehyde metabolite of lipid peroxidation. Lipid peroxidation is an autolytic mechanism leading to oxidative destruction of cellular membranes. Cd-induced lipid peroxidation in liver resulted in increasing the permeability of the cell membrane of hepatocytes and release of transaminases (ALT and AST) into the blood. The increase in synthesis of ALP indicates hepatic toxicity and biliary obstruction (Mauro \& Renze 2008, Toppo et al. 2015, Naik 2010). In addition, our results revealed reduction in the serum total protein and albumin, which possibly due to the reduced ability of liver to synthesize proteins because of $\mathrm{Cd}$ insult. These data have been also confirmed by histopathological examination of liver. As shown in Fig. 1C, Cd could cause severe damage in the liver cells.

Then, we investigated the toxic effect of $\mathrm{Cd}$ on the kidney. $\mathrm{Cd}$ increased the levels of serum creatinine and urea (Table 2). Alteration in the kidney function probably regarded to the oxidative damage induced by $\mathrm{Cd}$ which seen by decreased CAT and TAC along with increased MDA in kidney tissue (Table 3). Since $\mathrm{Cd}$ impaired the glomerular filtration, the creatinine and urea accumulated in the blood.

Proximal tubular epithelial cells are rich in mitochondria comparing to other renal cells. These mitochondria are needed for high-energy production required in reabsorption of albumin by endocytosis and amino acids with other molecules by active transportation (Birn \& Christensen 2006, Tojo \& Kinugasa 2012). Because, mitochondria are the main target for Cd inducing oxidative damage (Radosavljevici et al. 2012), the proximal convoluted tubule is the most affected part in the kidney as confirmed by our histopathological examination (Fig. 2C). In consistence with the 
previous studies, the decreased serum total protein and albumin indicates loss of these components in the urine as a result of $\mathrm{Cd}$ induced glomerular and tubular injury (Maunsbach 1966, Hjalm et al. 1996, Takeda et al. 2003, Birn \& Christensen 2006).

Opposite to the data obtained by Branka et al. 2001, Hounkpatin et al. 2013, this study has demonstrated a normocytic normochromic anemia observed by marked decreases in RBCs count, Hb concentration, and HCT. This anemia might be attributed to the deficiency of erythropoietin hormone as a result of the impact of chronic $\mathrm{Cd}$ intoxication on the erythropoietin producing cells in the kidney (Horiguchi et al. 2006).

Mbeh and his group have reported an increase in the total leukocytic count in rat-intoxicated with $\mathrm{Cd}$ (Mbeh et al. 2012). As seen in Table (1), there was a leukocytosis in Cd-treated rats. That increase was possibly occurred as a responsive mechanism to the degenerative changes caused by $\mathrm{Cd}$ insult in liver and kidney. Fig. $1 C \& 2 C$ show lymphocytic infiltrations in liver and kidney interstitia, respectively.

Next, we examined the protective effect of cinnamon against Cd toxicity. Cinnamon is known to have high contents of phenolic compounds and flavonoids, which act as potent antioxidants
(Yang et al. 2012). There many studies have investigated the antioxidant power of cinnamon against toxic effect of different agents such as deltamethrin, bisphenol, gentamicin, and paracetamol (Lamfon 2014, Morgan et al. 2014, Zahra et al. 2014, El-Komy et al. 2016, respectively). Consistently, in this study, rats coadministrated Cd with cinnamon showed significant decreases in ALT, AST, ALP, urea, and creatinine along with increases in the serum total protein and albumin compared to Cd-treated rats. These data strongly indicate a worthwhile improvement in the liver and kidney functions. Cinnamon also could counteract the negative effect of $\mathrm{Cd}$ on the erythrogram and leucogram. The ameliorative effect of cinnamon against $\mathrm{Cd}$-induced oxidative damage in liver and kidney may be due to increasing the activity of the antioxidant-defense system and scavenging the ROS as well as inhibiting lipid peroxidation (Dhaliwal et al. 1991, Albasha \& Azab, 2014, Morgan et al. 2014). As seen in Table (3), there was improvement in the antioxidant profile of the liver and kidney along with reduction in the MDA levels. Histopathological pattern of liver and kidney from rats treated with both $\mathrm{Cd}$ and cinnamon confirming the above-mentioned data (Fig. 1D and 2D).
A

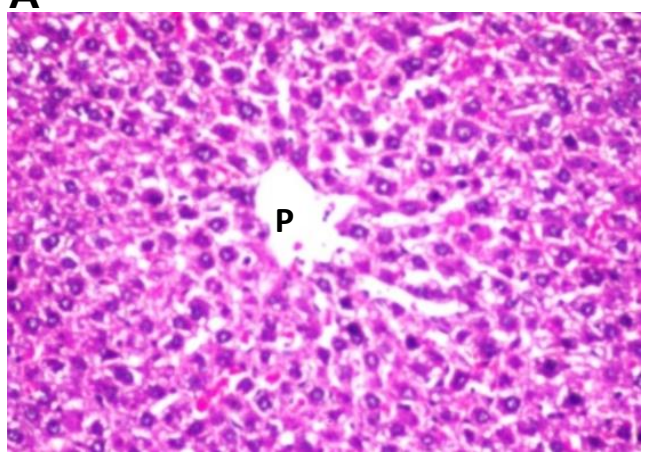

C

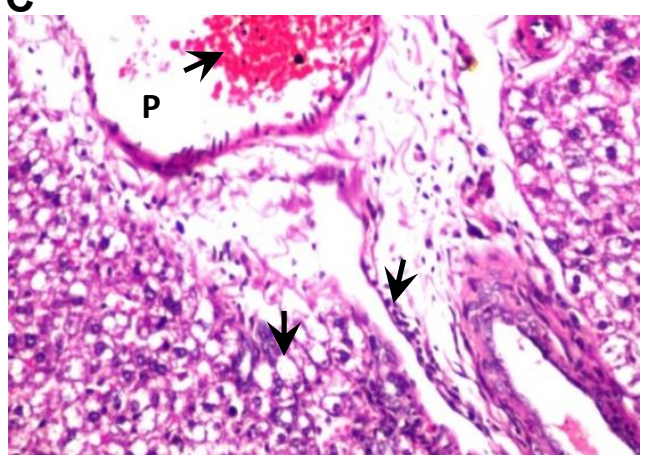

B

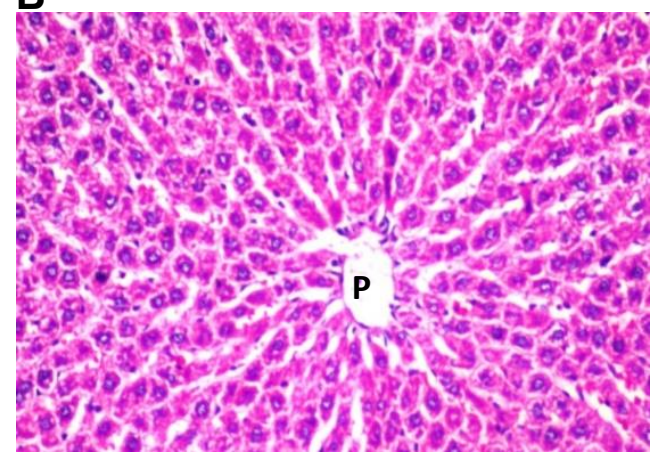

D

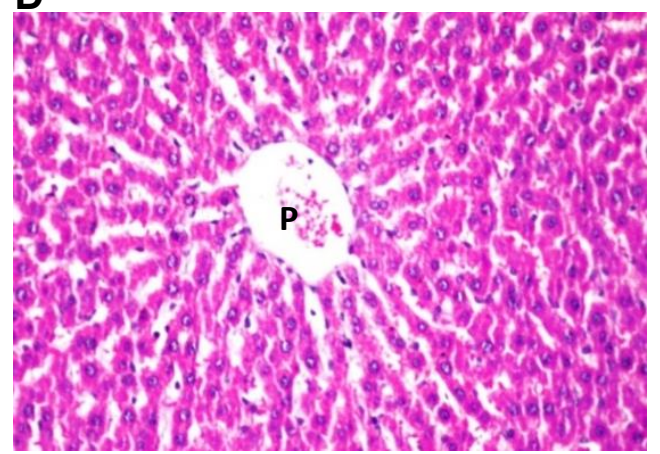

Fig. 1: Histopathological changes in liver after treatment with cadmium and / or cinnamon. (A and B) Liver sections from control and cinnamon groups (received distilled water and cinnamon; $200 \mathrm{mg} / \mathrm{kg}$, respectively) show normal liver architectures, uniform polyhedral hepatocytes with normal sinusoids. (C) Liver section from cadmium treated rat (received cadmium chloride $5 \mathrm{mg} / \mathrm{kg}$ ) shows portal vein congestion, edema in the portal area, diffuse hydropic degeneration (signet ring), piknotic nuclei, and lymphocytic infiltrations. (D) Liver section from a rat co-administrated cinnamon with cadmium shows improvement in the liver architecture shown by mild portal vein congestion with normal sinusoids. (PV: portal vein; H\&E; x64) 
A

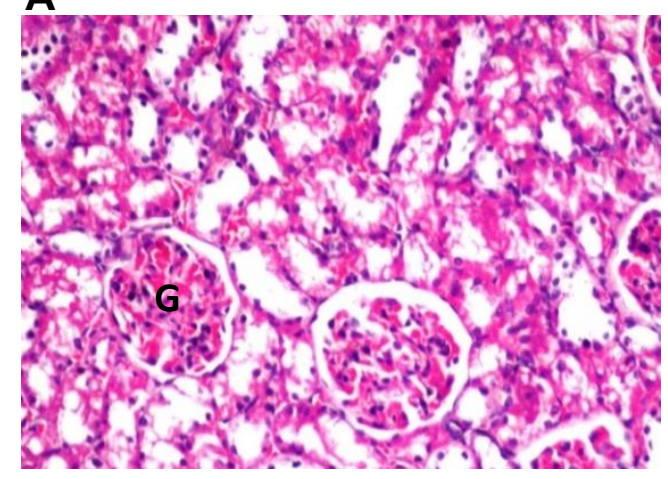

C

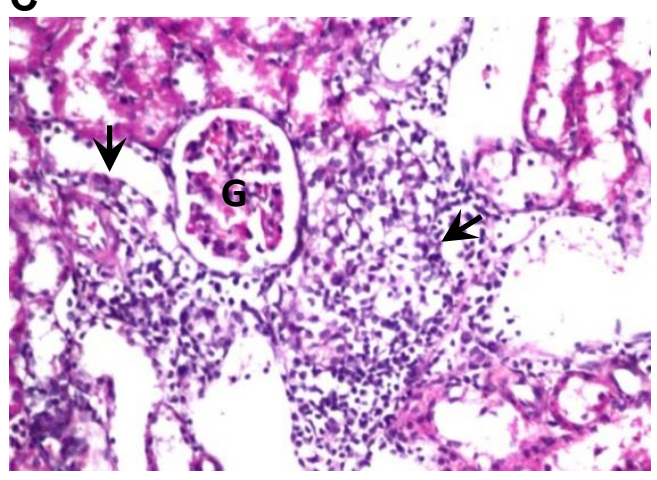

B

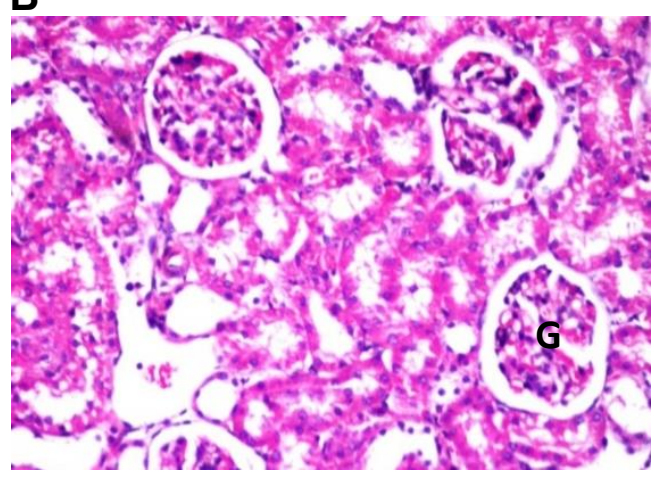

D

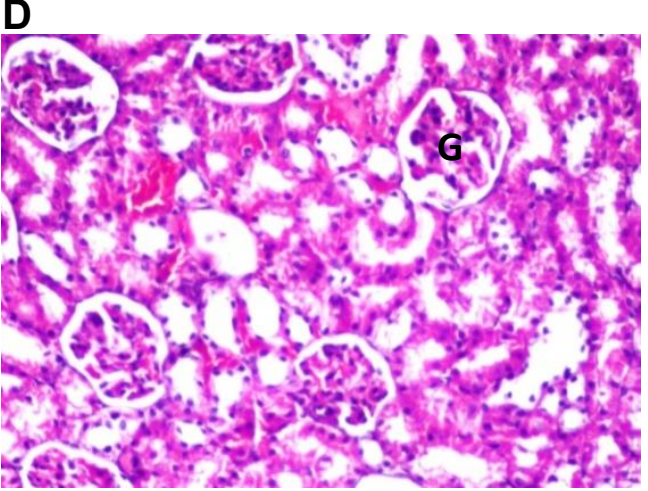

Fig. 2: Histopathological changes in kidney after treatment with cadmium and / or cinnamon. (A and B) kidney sections from control and cinnamon groups (received distilled water and cinnamon; $200 \mathrm{mg} / \mathrm{kg}$, respectively) show normal glomeruli and tubules. (C) Kidney section from cadmium treated rat (received cadmium chloride $5 \mathrm{mg} / \mathrm{kg}$ ) shows glomerular atrophy with obliterated capillaries, loss of brush border, tubular dilatation, and interstitial lymphocytic infiltration. (D) Kidney section from a rat co-administrated cinnamon with cadmium shows improvement in the kidney architecture shown by mild loss of brush border with no interstitial lymphocytic infiltration. (G: glomerulus; H\&E x64).

\section{Conclusion}

Cinnamon extract exhibited good protective effect against cadmium induced oxidative damage in liver and kidney, shown by its marked improvement on liver and kidney functions. This improvement may be due to the antioxidant power of cinnamon exerted by inhibition of ROS and stimulation of cellular antioxidant system.

\section{Acknowledgment}

The authors are thankful for the department of Forensic Medicine and Toxicology, Faculty of Veterinary Medicine, Benha University for providing all facilities needed for this work. The authors are also grateful to Dr. Ahmed Sheehab and IBEX-International Company for supporting our research.

\section{References}

[1] Abernethy DR, Destefano AJ, Cecil TL, Zaidi K \& Williams RL (2010) Metal impurities in food and drugs. Pharmaceutical Research 27, 750-755. https://doi.org/10.1007/s11095-010-0080-3.

[2] Aebi H (1984) Methods in Enzymology Journal 105, 121-126. https://doi.org/10.1016/S0076-6879(84)05016-3.

[3] Albasha MO \& Azab EA (2014) Effect of cadmium on the liver and amelioration by aqueous extracts of fenugreek seeds, rosemary, and cinnamon in guinea pigs: Histological and biochemical study. Cell Biology 2, 7-17. https://doi.org/10.11648/j.cb.20140202.11.

[4] Allen LC (1982) Clinical Chemistry Journal 28: 555.

[5] Amara S, Douki T, Garrel C., Favier, A., Rhouma K, Sakly M \& Abdelmelek H (2011) Effect of static magnetic field and cadmium on oxidative stress and DNA damage in rat cortex brain and hippocampus. Toxicolology Indian Health 27, 99-106. https://doi.org/10.1177/0748233710381887.

[6] Bagchi D, Bagchi M, Hassoun EA \& Stohs SJ (1996) Cadmiuminduced excretion of urinary lipid metabolites, DNA damage, glutathione depletion and hepatic lipid peroxidation in Sprague-Dawley rats. Biological Trace Element Research 52, 143-154 https://doi.org/10.1007/BF02789456.

[7] Banchroft JD, Stevens A, \& Turner DR (1996) Theory and practice of histological techniques. Fourth Edition. Churchil Livingstone, New York, London, San Francisco, Tokyo.

[8] Birn H \& Christensen EI (2006) renal albumin absorption in physiology and pathology. Kidney International 69, 440-449. https://doi.org/10.1038/sj.ki.5000141.

[9] Branka I, Ognjanovic S Z, Pavlovic SD, Maletic RV, Zikic AS, Stajn ZS \& Vojislav M P (2001) Protective role of vitamin E on antioxidant defense system and lipid peroxide concentration in the blood of rats acutely exposed to cadmium. Kragujevac Journal of Science 23, 115-126.

[10] Daniel EO \& Michael OE (2014) Histological effects of aqueous extract of cinnamon on the kidney functions of adult Wistar rats. SMU Medical Journal 1, 183-191.

[11] Demetrious JA, Drewes DA \& Gin JB (1974) Enzymes. In Clinical Chemistry-Principles and Techniques 2nd ed. RJ Henary, DC Cannon, JW Winkelman, Eds. Harper \& Row, Hagerstown MD, p 927.

[12] Dhaliwal H, Krishenbaum LA, Randhawa AK \& Singal PK (1991) Correlation between antioxidant changes during hypoxia and recovery on oxygenation. American Journal of Physiology 261, H632-H638.

[13] Doumas BT et al. (1971) Clinica Chimica Acta 31, 87 pp.

[14] Eidi A, Mortazavi P, Bazargan M \& Zaringhalam J (2012) Hepatoprotective activity of cinnamon ethanolic extract against $\mathrm{CCl} 4$ induced liver injury in rats. Excli Journal 11, 495-507.

[15] Eisenwiener HG (1976) Journal of clinical chemistry and clinical biochemistry 14, 261-264.

[16] Elkomy A, Aboubakr M, Soliman A, Abdeen A, Abdelkader A \& Hekal H (2016) Paracetamol induced hepatic toxicity and amelioration by cinnamon in rats. International Journal of Pharmacology and Toxicology 4, 187-190. https://doi.org/10.14419/ijpt.v4i2.6529.

[17] Gornall A (1949) the Journal of Biological Chemistry177, C 751.

[18] Hjälm G, Murray E, Crumley G, Harazim W, Lundgren S, Onyango I, Ek B, Larsson M, Juhlin C, Hellman P, Davis H, Akerström G, Rask L, \& Morse B (1996) Cloning and sequencing of human gp330, a Ca (2+)-binding receptor with potential intracellular signaling properties. European Journal of Biochemistry 239, 132-137. https://doi.org/10.1111/j.1432-1033.1996.0132u.x.

[19] Hollis L, Hogstrand C \& Wood CM (2001) Tissue specific cadmium accumulation, metallothionein induction, and tissue zinc and 
copper levels during chronic sublethal cadmium exposure in juvenile rainbow trout. Arch. Environmental Contamination and Toxicology. 41, 468-474. https://doi.org/10.1007/s002440010273.

[20] Hounkpatin ASY, Edorh P A, Guédénon P, Alimba CG, Ogunkanmi A, Dougnon T V, Boni G, Aissi KA, Montcho S, Loko F, Ouazzani N, Mandi L, Boko M \& Creppy EE (2013) Haematological evaluation of Wistar rats exposed to chronic doses of cadmium, mercury and combined cadmium and mercury. African Journal of Biotechnology 12, 3731-3737.

[21] Horiguchi H, Oguma E, Kayama F (2006) Cadmium and cisplatin damage erythropoietin-producing proximal renal tubular cells. Archives Toxicology 80, 680-686. https://doi.org/10.1007/s00204006-0093-1.

[22] Kara H, Karatap F \& Canatan H (2005) Effect of single dose cadmium chloride administration on oxidative stress in male and female rats. Turkish Journal of Veterinary and Animal Sciences 29 , $37-42$.

[23] Klaassen CD, Liu J \& Choudhuri S (1999) Metallothionein: An intracellular protein to protect against cadmium toxicity. Annual Review of Pharmacology and Toxicology 39, 267-294. https://doi.org/10.1146/annurev.pharmtox.39.1.267.

[24] Knapp JZ, Barber TA \& Lieberman A (1996) Liquid and surface born particles (Measurement Handbook). Marcel Dekker, pp.113.

[25] Koracevic D, Koracevic G, Djordjevic V, Andrejevic S \& Cosic V (2001) Method for the measurement of antioxidant activity in human fluids. Journal of Clinical Pathology 54, 356-361. https://doi.org/10.1136/jcp.54.5.356.

[26] Lakshmi DG, Kumar PR, Baharavi K, Annapurna P, Rajendar P \& Pankaj TB (2012) Protective effect of Tribulus terrestris Linn on liver and kidney in cadmium intoxicated rats. Indian Journal of Expermental Biology 50, 141-146.

[27] Lamfon NA (2014) Cinnamon aqueous extract ameliorates deltamethrin-induced hepatotoxicity in albino rats. Research Journal of Pharmaceutical, Biological and Chemical Sciences 5, 898-905.

[28] Liu J, Liu Y, Michalska AE, Choo KH \& Klaassen CD (1996) Distribution and retention of cadmium in metallothionein I and II null mice. Toxicology and Applied Pharmacology 136, 260-268. https://doi.org/10.1006/taap.1996.0033.

[29] Massanyi P, Tataruch F, Slamecka J, Toman RC \& Jurcik R (2003) Accumulation of lead, cadmium, and mercury in liver and kidney of the brown hare (Lepus europaeus) in relation to the season, age, and sex in the West Slovakian Lowland. Journal of Environmental Science and Health 39, 1299-1309. https://doi.org/10.1081/ESE$\underline{120021127}$.

[30] Maunsbach AB (1966) Albumin absorption by renal proximal tubule cells. Nature, 212, 546-547. https://doi.org/10.1038/212546a0.

[31] Mauro P \& Renze B (2008) In: Fundamentals of Clinical Chemistry. 6th ed. p325.

[32] Mbeh UE, Francis CO, Edet OA, Nelson CO, Stella CB \& Promise N (2012) Reversal of cadmium induced toxicity following dietary supplementation with garlic, ginger and cabbage in male Wistar rats. Journal of Natural Product and Plant Resources 2, 169-174.

[33] Morgan AM, El-Ballal SS, El-Bialy BE \& EL-Boraie NB (2014) Studies on the potential protective effect of cinnamon against bisphenol A- and octylphenol-induced oxidative stress in male albino rats. Toxicology Reports 1, 92-101. https://doi.org/10.1016/j.toxrep.2014.04.003.

[34] Moselhy SS \& Ali HK (2009) Hepatoprotective effect of cinnamon extracts against carbon tetrachloride induced oxidative stress and liver injury in rats. Biology Research 2, 93-98. https://doi.org/10.4067/s0716-97602009000100009.

[35] Naik P (2010) Biochemistry. 3rd ed. Jaypee Publishers Ltd, Panama. P138-141, 565. https://doi.org/10.5005/jp/books/11094.

[36] Newairy AA, El-Sharaky AS, Badreldeen MM, Eweda SM \& Sheweita SA (2007) the hepatoprotective effects of selenium against cadmium toxicity in rats. Toxicology 242, 23-30. https://doi.org/10.1016/j.tox.2007.09.001

[37] Nigam D, Shukla GS \& Agarwal AK (1999) Glutathione depletion and oxidative damage in mitochondria following exposure to cadmium in rat liver and kidney. Toxicology Letters 106, 151-157. https://doi.org/10.1016/S0378-4274(99)00059-4.

[38] Nishida S, Kikuichi S, Yoshioka S, Tsubaki M, Fujii Y \& Matsuda $\mathrm{H}$ (2003) Induction of apoptosis in HL-60 cells treated with medicinal herbs. The American Journal of Chinese Medicine 31, 551-562. https://doi.org/10.1142/S0192415X03001211.

[39] Radosavljevici T, Mladenovici D, Ninkovic M, Vucevici D, Boricic I, Jesic-Vukicevic R, Šljivancanini T, Lopicic S \& Todorovic V (2012) Oxidative stress in rat liver during acute cadmium and ethanol intoxication. Journal of Serbian Chemical Society 77, 159-176. https://doi.org/10.2298/JSC110330174R.
[40] Rikans LE \& Yamano T (2000) Mechanisms of cadmium-mediated acute hepatotoxicity. Journal of Biochemical and Molecular Toxicology 14, 110-117. https://doi.org/10.1002/(SICI)10990461(2000)14:2<110::AID-JBT7>3.0.CO;2-J.

[41] Sakr SA \& Albarakai AY (2014) Effect of cinnamon on cypermethrin-induced nephrotoxicity in albino rats. International Journal of Advanced Research 2, 578-586.

[42] Santos FW, Oro T, Zeni G, Rocha JBT, Donascimento PC \& Nogueira CW (2004) Cadmium induced testicular damage and its response to administration of succimer and diphenyl diselenide in mice. Toxicology Letters 152, 255-263. https://doi.org/10.1016/j.toxlet.2004.05.009.

[43] Satoh K (1978) Serum lipid peroxide in cerebrovascular disorders determined by a new colorimetric method. Clinica Chemica Acta 90, 37-41. https://doi.org/10.1016/0009-8981(78)90081-5.

[44] Singh N, Rani P, Gupta M, Goel N \& Tandan N (2013) Effects of aqueous extract of Camellia sinensis (1.) O. kuntze on liver markers of cadmium treated rats. Journal of Biotechnology and Pharmaceutical Research 4, 89-93.

[45] Singh P, Chaudhary S, Patni A \& Sankhla V (2007) Effect cadmium chloride induced genotoxicity in bone marrow chromosomes of swiss albino mice and subsequent protective effects of Emblica officinalis and vitamin C. Journal of Herbal Medicine and Toxicology $1,67-71$.

[46] Stohs SJ, Bagchi D, Hassoun E, \& Bagchi M (2000) Oxidative mechanisms in the toxicity of chromium and cadmium ions. Journal of Environmental Pathology, Toxicology and Oncology 20, 77-88.

[47] Su L, Yin J, Charles D, Zhou K, Moore J \& Yu L (2007) Total phenolic contents, chelating capacities, and radical-scavenging properties of black peppercorn, nutmeg, rosehip, cinnamon and oregano leaf. Food Chemistry 100, 990-997. https://doi.org/10.1016/j.foodchem.2005.10.058.

[48] Takeda T, Yamazaki H \& Farquhar MG (2003) Identification of an apical sorting determinant in the cytoplasmic tail of megalin. American Journal of Physiology - Cell Physiology 284, C1105-C1113. https://doi.org/10.1152/ajpcell.00514.2002.

[49] Tojo A \& Kinugasa S (2012) Mechanisms of Glomerular Albumin Filtration and Tubular Reabsorption. International Journal of Nephrology 1-9. https://doi.org/10.1155/2012/481520.

[50] Toppo R, Roy BK, Gora RH, Baxla SL \& Kumar P (2015) Hepatoprotective activity of Moringa oleifera against cadmium toxicity in rats. Veterinary $\quad$ World 537-540. https://doi.org/10.14202/vetworld.2015.537-540.

[51] Tremellen K (2008) Oxidative stress and male infertility-a clinical perspectives. Human Reproduction Update 14, 243-258. https://doi.org/10.1093/humupd/dmn004.

[52] Tremellen K (2008) Oxidative stress and male infertility-a clinical perspectives. Human Reproduction Update 14, 243-258. https://doi.org/10.1093/humupd/dmn004.

[53] Tribowo JA, Arizal MH, Nashrullah M, Aditama AR \& Utama DG (2014) Oxidative stress of cadmium-induced ovarian rat toxicity. International Journal of Chemical Engineering and Applications 5, 254-258. https://doi.org/10.7763/IJCEA.2014.V5.389.

[54] Turner TT and Lysia JJ (2008) Oxidative stress: a common factor in testicular dysfunction. Journal of Andrology 29, 488-498. https://doi.org/10.2164/jandrol.108.005132.

[55] Yang CH, Li RX \& Chuang LY (2012) Antioxidant Activity of Various Parts of Cinnamomum cassia Extracted with Different Extraction Methods. Molecules 17, 7294-7304. https://doi.org/10.3390/molecules17067294.

[56] Yiin SJ, Chern CL, Sheu JY, Tseng WC \& Lin TH (1999) Cadmium-induced renal lipid peroxidation in rats and protection by selenium. Journal of Toxicology and Environmental Health 57, 403413. https://doi.org/10.1080/009841099157601.

[57] Z, Klin Chem u, kiln Biochem 8, 1976. 658 and 10, 1972. 182.

[58] Zahra AJ, Sedigheh T, Alaeyan JN, Jamali H, Alaeyan JM \& Alaeyan JA (2014) Histological effects of cinnamon on nephrotoxicity resulted from Gentamicin in rats. Advances in Environmental Biology 8, 11-14. 